\title{
UJI EFEK ANTIHIPERGLIKEMIK EKSTRAK ETANOL DAUN KACAPIRING (Gardenia augusta, Merr) PADA TIKUS PUTIH JANTAN GALUR WISTAR
}

\author{
ANTIHIPERGLIKEMIC EFFECT ETHANOLIC \\ EXTRACT OF KACAPIRING (Gardenia augusta, Merr) \\ LEAF AT WHITE RATS MALE STRAIN OF WISTAR
}

\author{
Faridah Baroroh, Nurfina Aznam, Hari Susanti \\ Fakultas Farmasi Universitas Ahmad Dahlan \\ Jl.Prof.Dr. Soepomo, SH (0274) 379418 \\ farida_b0702@yahoo.co.id
}

\section{Abstrak}

Daun kacapiring (Gardenia augusta, Merr) sering digunakan secara tradisional untuk pengobatan diabetes mellitus. Penelitian ini dilakukan untuk mengetahui apakah ekstrak etanol daun kacapiring dapat menurunkan kadar glukosa darah pada tikus putih jantan galur Wistar dan seberapa besar efek antihiperglikemiknya jika dibandingkan dengan obat antidiabetes glibenklamid. Penelitian ini menggunakan metode uji toleransi glukosa oral dengan pembebanan glukosa dosis 4,5 $\mathrm{g} / \mathrm{kgBB}$. Hewan uji yang digunakan tikus putih jantan galur Wistar umur 2-3 bulan, berat badan 180-250 gram, sebanyak 24 ekor yang dibagi menjadi 4 kelompok masing-masing kelompok terdiri dari 6 ekor tikus. Kelompok I sebagai kelompok kontrol negatif diberi CMC-Na 1\%, kelompok II sebagai kelompok kontrol positif diberi glibenklamid dosis $1,35 \mathrm{mg} / \mathrm{kgBB}$, kelompok III dan kelompok IV diberi ekstrak etanol daun kacapiring masing-masing dosis $500 \mathrm{mg} / \mathrm{kgBB}$ dan $250 \mathrm{mg} / \mathrm{kgBB}$. Glibenklamid dan ekstrak diberikan secara peroral 60 menit sebelum pemberian glukosa. Pengambilan darah melalui sinus orbitalis secara keseluruhan dilakukan pada menit ke-(-90), (-60), 0, 30, 60, 120, 180, 240, dan 300. Kadar glukosa darah diukur dengan metode enzimatik dengan pereaksi GOD PAP (Glucose Oxidase Phenol 4-Aminoantipirin) yang menghasilkan larutan merah dan absorbansi dibaca dengan spektrofotometer UV-Vis pada panjang gelombang $500 \mathrm{~nm}$. Hasil penelitian menunjukkan bahwa ekstrak etanol daun kacapiring dosis $500 \mathrm{mg} / \mathrm{kgBB}$ dan $250 \mathrm{mg} / \mathrm{kgBB}$ dapat berefek menurunkan kadar glukosa darah. Ekstrak etanol daun kacapiring dosis $500 \mathrm{mg} / \mathrm{kgBB}$ dan 250 
$\mathrm{mg} / \mathrm{kg}$ dapat menurunkan kadar glukosa darah sebesar 58,97\% dan 80,60\% dibanding glibenklamid dosis $1,35 \mathrm{mg} / \mathrm{kgBB}$ yang dapat menurunkan kadar glukosa darah sebesar $73,93 \%$.

Kata kunci : diabetes mellitus antihiperglikemik, kacapiring

\section{Abstract}

Kacapiring leaf (Gardenia augusta, Merr) was often used in traditional drugs for treatment diabetes mellitus. This research aim to know the antihiperglycemic effect ethanolic extract of kacapiring leaf on white rats male strain of Wistar and how much antihiperglycemic effect compared with glibenklamid. This study used oral glucose tolerance test method with loading glucose $4,5 \mathrm{~g} / \mathrm{kgW}$. Tested animal where 24 white male rats strain of Wistar age 2-3 months with weight 180-250 gram, devided into 4 groups, each groups consist of 6 rats. Group I was as negative control group given CMC-Na 1\%, group II was as positive control group given glibenklamid dose 1,35 $\mathrm{mg} / \mathrm{kgBB}$, group III and IV where given ethanolic extract of kacapiring leaf dose 500 $\mathrm{mg} / \mathrm{kgBB}$ and $250 \mathrm{mg} / \mathrm{kgBB}$. Glibenklamid and exstract are given orally 60 minutes before glucose. Blood was taken from orbitalis sinus at minute (-90), (-60), 0, 30, 60, 120, 180, 240, and 300. Blood glucose level was determined with GOD PAP enzymatic method, absorbance was observed using spectrophotometer at $500 \mathrm{~nm}$. The result of the study was performed by giving ethanolic extract of kacapiring leaf dose $500 \mathrm{mg} / \mathrm{kgW}$ and $250 \mathrm{mg} / \mathrm{kgW}$ had antihiperglycemic effect. Ethanolic extract of kacapiring leaf dose $500 \mathrm{mg} / \mathrm{kgW}$ and $250 \mathrm{mg} / \mathrm{kgW}$ could reduce blood glucoce level $58,97 \%$ and 80,60\% compared with glibenklamid dose $1,35 \mathrm{mg} / \mathrm{kgW}$ could reduce blood glucoce level $73,93 \%$.

Key words : diabetes mellitus, antihiperglycemic, kacapiring 


\section{PENDAHULUAN}

Prevalensi diabetes mellitus makin meningkat dari tahun ke tahun. Berdasarkan penelitian di Jakarta, terjadi peningkatan $1,7 \%$ pada tahun 1982 , $5,7 \%$ pada tahun 1993 , dan $12,8 \%$ pada tahun 2001. Pada tahun 2000 penderita diabetes diperkirakan 5,5 juta, sedangkan pada tahun 2020 dimana jumlah penduduk Indonesia di atas 20 tahun sekitar 178 juta, dengan prevalensi penderita diabetes $4,6 \%$, penderita diabetesnya diperkirakan 8,2 juta (Wiyono, 2004).

Diabetes tipe 2 merupakan diabetes yang banyak terjadi pada orang dewasa. Selain terjadinya penurunan kepekaan jaringan pada insulin, dapat terjadi pula suatu defisiensi respon sel $\beta$ pankreas terhadap glukosa. Kedua kerusakan ini diperparah dengan terjadinya hiperglikemia, dan kedua kerusakan ini dapat diperbaiki melalui terapi yang mengurangi hiperglikemia tersebut (Katzung, 2002).

Glibenklamid merupakan obat antidiabetika golongan sulfonilurea yang sukar larut dalam air dan larut dalam alkohol. Setelah pemberian oral, glibenklamid dapat diabsorbsi dengan cepat dan baik. Glibenklamid diberikan dalam dosis tunggal, dosis sehari $5-20$ mg. Bila pemberian dihentikan, obat akan bersih dari serum setelah 36 jam. Glibenklamid menurunkan kadar glukosa darah pada diabetes mellitus tipe 2 dan tidak pada diabetes mellitus tipe 1 . Mekanisme kerjanya menstimulasi sekresi insulin, meskipun secara kualitatif golongan sulfonilurea mempunyai efek farmakologi yang sama tetapi secara kuantitatif ada bedanya.
Efek hipoglikemik glibenklamid $5 \mathrm{mg}$ sama dengan tolbutamid $1000 \mathrm{mg}$, klorpropamid $250 \mathrm{mg}$, atau tolazamid $250 \mathrm{mg}$ (Ganiswarna, 1995). Struktur glibenklamid dapat dilihat pada gambar 1.

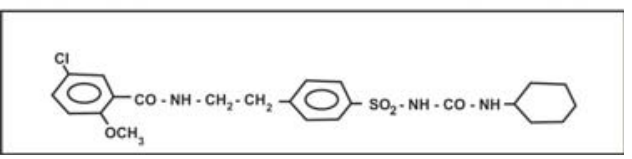

Gambar 1. Struktur glibenklamid (5-Kloro-2-metoksibenzamido-etil-benzenasulf onil-3-sikloheksilurea) (Anonim, 1995).

Daun kacapiring mengandung saponin, flavonoid, polifenol, crocetin, crosin, dan scandosida. Secara empiris daun kacapiring merupakan salah satu tanaman obat yang digunakan untuk pengobatan diabetes mellitus (Wijayakusuma, 2000). Dari kandunga zat aktif tersebut belum diketahui senyawa apa yang berefek menurunkan kadar glukosa darah. Tujuan dari penelitian ini adalah untuk mengetahui apakah ekstrak etanol daun kacapiring dapat menurunkan kadar glukosa darah dan seberapa besar efek antihiperglikemik ekstrak etanol daun kacapiring dibandingkan dengan obat antidiabetes glibenklamid.

\section{METODE PENELITIAN}

\section{Bahan}

Bahan uji yang digunakan adalah daun kacapiring (Gardenia augusta, Merr) dari Bandungan Kabupaten Semarang, baik daun muda maupun daun tua yang terkena sinar matahari sempurna. Cairan penyari etanol $70 \%$, CMC-Na 1\%, Glibenklamid, Aquadest, 
Glukosa (D-Glukosa monohidrat), pereaksi GOD PAP (Glucose Oxidase Phenol 4-Aminoantipyrine) dari Diasys. Hewan uji yang digunakan tikus putih jantan galur Wistar umur 2-3 bulan, sehat, berat badan 180-250 gram.

\section{Alat}

Almari pengering, alat penyerbuk, timbangan analitik, kompor listrik, penangas air, cawan porselin, mortir, stamper, timbangan hewan, jarum suntik oral, tabung plastik Ependorf, mikrohematokrit, almari pendingin, sentrifuge, mikropipet 5-50 $\mu 1$, mikro-

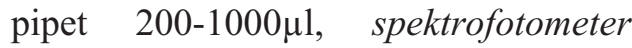
$U V$-Vis dan alat-alat gelas.

\section{JALAN PENELITIAN}

Determinasi daun kacapiring dilakukan di Laboratorium Biologi Universitas Ahmad Dahlan Yogyakarta mengacu pada buku Flora of Java (Backer dan Van den Brink, 1965) untuk mengetahui kebenaran daun kacapiring tersebut. Serbuk daun kacapiring kering disari dengan etanol $70 \%$ secara maserasi selama dua hari, sari etanol yang diperoleh diuapkan di atas penangas air dalam cawan perselin sampai menjadi kental atau semi padat. Ekstrak disuspensikan ke dalam CMC-Na 1\% sehingga diperoleh larutan stok $4,0 \mathrm{~g} / 100 \mathrm{ml}$ (dosis $500 \mathrm{mg} / \mathrm{KgBB}$, tiap pemberian peroral $2,5 \mathrm{ml}$ )

\section{Penentuan dosis untuk tikus}

Dosis ekstrak : $500 \mathrm{mg} / \mathrm{kgBB}$ dan $250 \mathrm{mg} / \mathrm{kgBB}$

Dosis glibenklamid : $1,35 \mathrm{mg} / \mathrm{kgBB}$

Dosis glukosa $\quad: 4,5 \mathrm{~g} / \mathrm{kgBB}$
Penelitian Pendahuluan

Penetapan waktu pembebanan
glukosa

Sebanyak 9 ekor tikus dibagi secara acak menjadi 3 kelompok, tikus dipuasakan selama 18 sampai 20 jam dengan tetap diberi minum ad libitum sebelum perlakuan. Tiap kelompok diberi perlakuan glibenklamid dosis 1,35 $\mathrm{mg} / \mathrm{kgBB}$ peroral, kemudian diberi glukosa dosis $4,5 \mathrm{~g} / \mathrm{kgBB}$ per oral selang waktu 40 menit untuk kelompok I, 50 menit untuk kelompok II, dan 60 menit untuk kelompok III dihitung dari saat pemberian glibenklamid. Darah diambil dari sinus orbitalis pada menit ke -30 sebelum pemberian glibenklamid, menit ke-0, 30, 60, 120, dan 180 setelah pemberian glukosa. Kadar glukosa darah ditetapkan secara enzimatik dengan pereaksi GOD PAP dan absorbansi dibaca dengan spektrofotometer UV-Vis pada panjang gelombang $500 \mathrm{~nm}$, kemudian dicari harga luas daerah dibawah kurva dari menit ke-0 sampai menit ke-180 (LDDK 0-180) tiap kelompok dihitung dan dibandingkan. Waktu pembebanan glukosa yang dipilih adalah pembebanan glukosa yang memberikan nilai $\left(\operatorname{LDDK}_{0-180}\right)$ terkecil.

\section{Pengelompokan dan Perlakuan hewan uji}

Hewan uji dibagi secara acak menjadi 4 kelompok masing-masing terdiri dari 6 ekor tikus putih jantan. Tikus dipuasakan terlebih dahulu selama 18 sampai 20 jam dengan tetap diberi minum ad libitum sebelum perlakuan. Tiap kelompok tikus diberi perlakuan sebagai berikut 
Kelompok I : sebagai kontrol negatif, diberi larutan CMC Na1\%,

60 menit kemudian diberi glukosa 4,5 $\mathrm{mg} / \mathrm{kgBB}$

\begin{tabular}{|c|c|}
\hline Kelompok II & $\begin{array}{l}\text { : sebagai } \\
\text { positif, } \\
\text { glibenklamid } \\
\text { mg/kgBB }\end{array}$ \\
\hline
\end{tabular}

60 menit kemudian diberi glukosa 4,5 $\mathrm{mg} / \mathrm{kgBB}$

Kelompok III : perlakuan ekstrak etanol daun kacapiring $500 \mathrm{mg} / \mathrm{kgBB}$

60 menit kemudian diberi glukosa 4,5 $\mathrm{mg} / \mathrm{kgBB}$

Kelompok IV : perlakuan ekstrak etanol daun kacapiring $250 \mathrm{mg} / \mathrm{kgBB}$

60 menit kemudian diberi glukosa 4,5 $\mathrm{mg} / \mathrm{kgBB}$

Darah diambil dari sinus orbitalis pada menit ke-(-90) sebelum perlakuan, untuk mengetahui kadar normal glukosa darah tikus, dimana menit ke- 0 adalah waktu saat pembebanan glukosa. Menit ke-(-60) adalah waktu pengambilan darah hewan uji segera setelah diberi glibenklamid atau suspensi ekstrak etanol daun kacapiring sebelum diberi glukosa pada menit ke- 0 . Setelah hewan uji diberi glukosa maka pengambilan darah dilakukan pada menit ke-30, 60, $120,180,240$, dan 300, sehingga pengambilan darah setiap hewan uji dari sinus orbitalis secara keseluruhan dilakukan pada menit ke-(-90), (-60), 0, 30, 60, 120, 180,240 , dan 300 . Volume darah yang diambil $\pm 1 \mathrm{ml}$ kemudian ditampung dalam tabung plastik ependorf dan dibiarkan membeku agar serum memisah dengan darah. Agar serum memisah dengan sempurna, darah yang ditampung dalam tabung plastik ependorf di sentrifuge selama 15 sampai 20 menit dengan kecepatan $2500 \mathrm{rpm}$. Serum yang telah memisah disimpan dalam almari pendingin pada suhu $2-8^{\circ} \mathrm{C}$ agar tidak rusak selama penyimpanan. Setelah itu ukur kadar glukosanya dengan cara $10 \mu 1$ serum ditambah campuran pereaksi Diasys sebanyak $1000 \mu 1$ kemudian divortek 1 menit agar campur sempurna, setelah dibiarkan selama 20 menit pada suhu kamar $25-28^{\circ} \mathrm{C}$ absorbansi dibaca dengan spektrofotometer $U V$-Vis pada panjang gelombang $500 \mathrm{~nm}$ dan dihitung kadar glukosa darah (mg/dl).

\section{Analisis Data}

Data yang berupa kadar glukosa darah dianalisis dengan $\mathrm{LDDK}_{0-\mathrm{n}}$ dengan rumus trapesium untuk masing-masing perlakuan yaitu:

$\left.\operatorname{LDDK}_{0-\mathrm{n}}=\left[\frac{\mathrm{t}_{1}-\mathrm{t}_{0}}{2} \mathrm{X}\left(\mathrm{C}_{0}+\mathrm{C}_{1}\right)\right]+\left[\frac{\mathrm{t}_{2}-\mathrm{t}_{1}}{2}{ }_{\mathrm{xic}}{ }_{2}+\mathrm{C}_{1}\right)\right]+\ldots . .+\left[\frac{\mathrm{t}_{\mathrm{n}}-\mathrm{t}_{\mathrm{n}-1}}{2} \mathrm{X}\left(\mathrm{C}_{\mathrm{n}}+\mathrm{C}_{\mathrm{n}-1}\right)\right]$

Data-data tersebut kemudian dianalisis secara statistik menggunakan program SPSS 12 for windows. Diawali dengan uji Kolmogorof Smirnov untuk menentukan data tersebut terdistribusi normal atau tidak. Kemudian dilanjutkan dengan uji Levene untuk menentukan varian homogen atau tidak dari data tersebut. Jika data terdistribusi normal dan varian homogen maka diuji dengan 
analisis varian satu jalur (ANAVA) dan dilanjutkan dengan uji LSD dengan taraf kepercayaan $95 \%$, sedangkan jika data tersebut tidak terdistribusi normal dan tidak homogen, maka diuji dengan Kruskal-Wallis dan Mann-Withney dengan taraf kepercayaan $95 \%$.

Untuk mengetahui kemampuan sediaan dalam menurunkan kadar glukosa darah, dihitung dengan rumus persentase penurunan kadar glukosa darah yaitu :

LDDK $_{0-300}$ kontrol negatif - $\mathrm{LDDK}_{0-300}$ perlakuan

Persentase $=$

LDDK0-300 kontrol negatif

\section{Hasil dan Pembahasan}

Determinasi tanaman daun kacapiring dilakukan untuk memastikan bahwa tanaman yang digunakan dalam penelitian sesuai dengan pustaka. Determinasi dilakukan di laboratorium Biologi MIPA Universitas Ahmad Dahlan, dengan hasil determinasi tanaman kacapiring sebagai berikut :

1b-2b-3b-4b-6b-7b-9b-10b-11b-12a-84 b- $88 b-89 b-91 b$

(105.Apocinacea). 105b-106b-107b (Gardenia augusta, Merr).

Determinasi tanaman dilakukan dengan buku Flora of Java (Backer dan Van den Brink, 1965). Dari hasil determinasi dapat diperoleh kepastian bahwa tanaman yang digunakan dalam penelitian ini adalah tanaman kacapiring (Gardenia augusta, Merr).

\section{Penetapan waktu pembebanan glukosa}

Waktu pembebanan glukosa merupakan waktu optimum dimana pemberian glukosa peroral dilakukan pada saat yang tepat sehingga efek penurunan kadar glukosa darah sediaan uji tercapai paling tinggi. Penilaian efek penurunan kadar glukosa darah didasarkan pada nilai LDDK $_{0-180}$ (Luas Daerah Di Bawah Kurva dari menit ke-0 sampai menit ke-180). Jadi glibenklamid memberikan efek penurunan glukosa darah paling tinggi apabila memiliki LDDK paling kecil. Hasil percobaan menunjukkan bahwa pembebanan glukosa paling efektif dilakukan pada menit ke-60 setelah pemberian glibenklamid, dimana nilai $\mathrm{LDDK}_{0-180}$ yang paling kecil yang merupakan nilai yang paling besar daya antihiperglikemiknya. Dengan demikian menit ke-60 digunakan sebagai waktu penetapan pemberian sediaan sebelum pembebanan glukosa untuk kelompok perlakuan dengan ekstrak etanol daun kacapiring.

\section{Hasil Penelitian Efek Antihiper- glikemik Ekstrak Etanol Daun Kacapiring}

Penelitian ini bertujuan untuk mengetahui adanya efek antihiperglikemik dari ekstrak etanol daun kacapiring dalam bentuk suspensi dalam larutan CMC-Na 1\% pada tikus putih jantan galur Wistar menggunakan uji toleransi glukosa oral. Pembebanan glukosa akan menyebabkan peningkatan kadar glukosa darah secara cepat dan dapat diturunkan secara cepat oleh zat-zat yang berefek antihiperglikemik.

Untuk memperkecil pengaruh variasi biologis antara tikus terhadap hasil penelitian adalah semua tikus yang digunakan mempunyai jenis dan galur 
yang sama yaitu tikus putih jantan galur Wistar dengan umur dan berat badan yang kurang lebih sama yaitu 2-3 bulan, berat 180-250 gram. Tikus jantan lebih diutamakan daripada tikus betina karena kondisi hormonal tikus jantan relatif stabil sehingga tidak banyak mempengaruhi metabolisme dalam tubuhnya. Tikus yang digunakan adalah tikus normal yang dibebani glukosa tanpa dirusak pankreasnya, karena berdasarkan teori bahwa dengan pembebanan glukosa peroral akan menyebabkan peningkatan kadar glukosa darah secara cepat dan dapat diturunkan secara cepat pula dengan zat-zat yang berefek antihiperglikemik.

Sebelum perlakuan, tikus dipuasakan terlebih dahulu selama 18-20 jam dengan tetap diberi minum ad libitum, dengan tujuan agar tikus tidak mengalami dehidrasi. Puasa pada hewan percobaan ini bertujuan untuk mengurangi pengaruh asupan makanan terhadap kadar glukosa darah. Pembebanan glukosa dilakukan pada waktu yang sama yaitu 60 menit setelah perlakuan, hal ini mengacu pada hasil waktu pembebanan glukosa.

Darah diambil dari sinus orbitalis mata pada menit ke-(-90), (-60), 0, 30, $60,120,180,240$, dan 300. Untuk memisahkan serum dan plasmanya dilakukan sentrifugasi selama 15-20 menit pada $2500 \mathrm{rpm}$, kemudian diambil $10 \mu \mathrm{l}$ serum untuk direaksikan dengan reagen GOD PAP sebanyak $1000 \mu 1$. Metode ini adalah cara penetapan kadar glukosa darah atau serum menggunakan glucose oksidase, peroksidase dan akseptor oksigen.
Kadar glukosa darah ditetapkan dengan metode enzimatik menggunakan pereaksi GOD PAP dengan alat spektrofotometer $U V$-Vis pada panjang gelombang $500 \mathrm{~nm}$. Reaksi pembentukan warna pada penetapan kadar glukosa darah metode enzimatik dengan pereaksi GOD PAP dapat dilihat pada gambar 2. Reaksi yang terjadi adalah glukosa dioksidasi oleh enzim glucose oksidase (GOD) dengan adanya $\mathrm{O}_{2}$ menjadi asam glukonat disertai pembentukan $\mathrm{H}_{2} \mathrm{O}_{2}$. Hidrogen peroksida $\left(\mathrm{H}_{2} \mathrm{O}_{2}\right)$ yang terjadi dengan adanya enzim peroksidase (PAP) akan membebaskan $\mathrm{O}_{2}$ yang selanjutnya mengoksidasi akseptor kromogen (4-Amino) yang mengandung quinonimin (senyawa berwarna merah). Besarnya intensitas warna tersebut berbanding lurus dengan glukosa yang ada. Selanjutnya absorbansi dibaca dengan spektrofotometer pada panjang gelombang $500 \mathrm{~nm}$.

Kadar glukosa darah pada menitmenit tertentu untuk tiap-tiap hewan uji

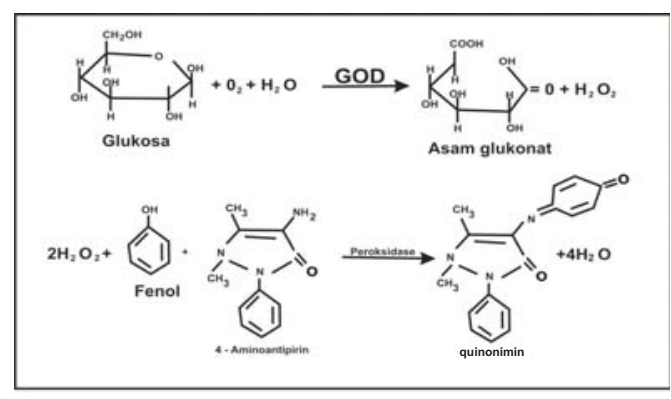

Gambar 2. Reaksi pembentukan warna pada penetapan kadar glukosa darah metode enzimatik (Diasys, 1999).

pada semua kelompok perlakuan digunakan untuk menghitung $\mathrm{LDDK}_{0-300}$ (Luas Daerah Di Bawah Kurva dari 
menit ke-0 sampai menit ke-300) dan dibandingkan hasilnya pada tiap kelompok perlakuan. Purata kadar glukosa darah tikus pada menit-menit tertentu untuk semua kelompok dapat dilihat pada tabel I.

Untuk membandingkan efek antihiperglikemik antar kelompok, maka
Dari purata kadar glukosa darah pada menit menit tertentu untuk semua kelompok perlakuan dapat dibuat kurva hubungan antara kadar glukosa darah terhadap waktu untuk semua kelompok perlakuan dapat dilihat pada gambar 3 .

Dari nilai $\mathrm{LDDK}_{0-300}$ diatas dapat dikatakan bahwa yang menunjukkan

Tabel I. Purata kadar glukosa darah tikus yang dibebani glukosa

\begin{tabular}{|c|c|c|c|c|c|c|c|}
\hline \multirow{2}{*}{$\mathrm{K}$} & \multicolumn{7}{|c|}{ Purata kadar glukosa darah $\pm \mathrm{SD}(\mathrm{mg} / \mathrm{dl})$ pada menit ke } \\
\cline { 2 - 8 } & 0 & 30 & 60 & 120 & 180 & 240 & 300 \\
\hline I & $94,35 \pm 0,60$ & $141,29 \pm 0,83$ & $146,11 \pm 0,86$ & $161,83 \pm 0.61$ & $164,79 \pm 0,87$ & $167,37 \pm 0,71$ & $165,83 \pm 0,68$ \\
\hline II & $94,74 \pm 0,47$ & $125,07 \pm 0,64$ & $122,32 \pm 1,54$ & $115,63 \pm 0,76$ & $110,07 \pm 1,95$ & $102,30 \pm 1,38$ & $96,22 \pm 1,55$ \\
\hline III & $94,64 \pm 0,68$ & $132,84 \pm 0,90$ & $127,33 \pm 0,80$ & $125,27 \pm 0,80$ & $120,54 \pm 1,27$ & $114,35 \pm 1,31$ & $108,01 \pm 1,17$ \\
\hline IV & $94,30 \pm 0,71$ & $128,51 \pm 0,74$ & $113,91 \pm 0,63$ & $108,65 \pm 0,52$ & $101,57 \pm 0,76$ & $99,33 \pm 1,09$ & $97,00 \pm 0,78$ \\
\hline
\end{tabular}

Keterangan :

$\mathrm{K}$

\section{: Kelompok}

Kelompok I : Kontrol negatif dengan perlakuan CMC-Na 1\%

Kelompok II : Kontrol positif dengan perlakuan glibenklamid $1,35 \mathrm{mg} / \mathrm{kgBB}$

Kelompok III : Perlakuan dengan ekstrak etanol daun kacapiring dosis $500 \mathrm{mg} / \mathrm{kgBB}$

Kelompok IV : Perlakuan dengan ekstrak etanol daun kacapiring dosis $250 \mathrm{mg} / \mathrm{kgBB}$

dihitung perubahan kadar glukosa darah dari tiap kelompok perlakuan, kemudian dihitung luas daerah di bawah kurva dari menit ke-0 sampai menit ke-300 $\left(\operatorname{LDDK}_{0-300}\right)$. Dari nilai $\mathrm{LDDK}_{0-300}$ setiap kelompok perlakuan menunjukkan jumlah perubahan kadar glukosa yang ada dalam darah selama 300 menit karena pengaruh masing-masing perlakuan dalam setiap kelompok. Nilai LDDK $_{0-300}$ berbanding terbalik dengan efek antihiperglikemik dari suatu sediaan. Semakin kecil nilai LDDK, maka semakin besar efek antihiperglikemik suatu sediaan. Data perubahan kadar glukosa darah dan $\mathrm{LDDK}_{0-300}$ dapat dilihat pada tabel II.

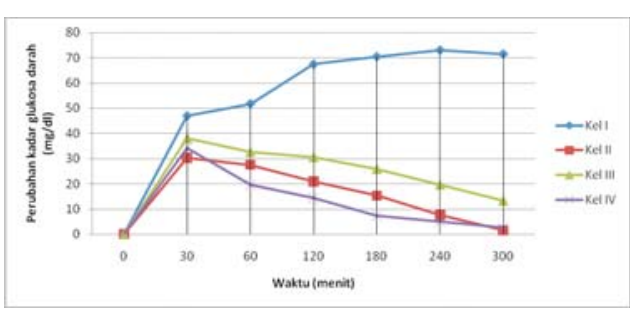

Gambar 3. Kurva purata perubahan kadar glukosa darah terhadap waktu untuk semua kelompok

efek penurunan kadar glukosa darah paling besar adalah perlakuan ekstrak etanol daun kacapiring dosis 250 $\mathrm{mg} / \mathrm{kgBB}$, diikuti perlakuan gliben- 
Tabel II. Purata perubahan kadar glukosa darah tikus yang dibebani glukosa dan LDDK $_{0-300}$ pada kelompok I, II, III, dan IV

\begin{tabular}{|c|c|c|c|c|c|c|c|c|}
\hline \multirow[t]{2}{*}{$\mathrm{K}$} & \multicolumn{7}{|c|}{ Purata perubahan kadar glukosa darah $\pm \mathrm{SD}(\mathrm{mg} / \mathrm{dl})$ pada menit ke } & \multirow{2}{*}{$\begin{array}{c}\text { LDDK0-300 } \\
\pm \mathrm{SD}\end{array}$} \\
\hline & 0 & 30 & 60 & 120 & 180 & 240 & 300 & \\
\hline I & 0 & $46,94 \pm 0,23$ & $51,76 \pm 0,26$ & $67,48 \pm 0,00$ & $70,44 \pm 0,26$ & $73,02 \pm 0,10$ & $71,48 \pm 0,08$ & $\begin{array}{c}18503,98 \\
\pm 182,43 \\
\end{array}$ \\
\hline II & 0 & $30,33 \pm 0,17$ & $27,58 \pm 1,07$ & $20,89 \pm 0,29$ & $15,33 \pm 1,47$ & $7,56 \pm 0,91$ & $1,48 \pm 1,08$ & $\begin{array}{l}4824,65 \\
\pm 323,11\end{array}$ \\
\hline III & 0 & $38,19 \pm 0,22$ & $32,69 \pm 0,12$ & $30,63 \pm 0,12$ & $25,90 \pm 0,59$ & $19,71 \pm 0,62$ & $13,36 \pm 0,48$ & $\begin{array}{c}7592,55 \\
\pm 1115,95 \\
\end{array}$ \\
\hline IV & 0 & $34,21 \pm 0.02$ & $19,61 \pm 0,08$ & $14,35 \pm 0,19$ & $7,27 \pm 0,04$ & $5,03 \pm 0,37$ & $2,70 \pm 0,06$ & $\begin{array}{l}3589,37 \\
\pm 138,20\end{array}$ \\
\hline
\end{tabular}

Keterangan :

K

Kelompok I : Kontrol negatif dengan perlakuan CMC-Na $1 \%$

Kelompok II : Kontrol positif dengan perlakuan glibenklamid 1,35 mg/kgBB

Kelompok III : Perlakuan dengan ekstrak etanol daun kacapiring dosis $500 \mathrm{mg} / \mathrm{kgBB}$

Kelompok IV : Perlakuan dengan ekstrak etanol daun kacapiring dosis $250 \mathrm{mg} / \mathrm{kgBB}$

klamid 1,35 mg/kgBB sebagai kontrol positif, kemudian ekstrak etanol daun kacapiring dosis $500 \mathrm{mg} / \mathrm{kgBB}$.

\section{Hasil Uji Statistik Data LDDK $_{0-300}$}

Karena hasil uji normalitas data tidak terpenuhi, maka untuk mengetahui adanya perbedaan efek menurunkan kadar glukosa darah pada tiap kelompok, dilakukan uji statistik non parametrik dengan uji Kruskal-Wallis. Hasil uji Kruskal-Wallis menunjukkan ada perbedaan yang signifikan antar kelompok $(a ́<0,05)$ dengan harga signifikansi sebesar 0,000 . Hal ini menunjukkan ada perbedaan yang bermakna antar kelompok perlakuan.

Untuk mengetahui ada tidaknya perbedaan antara pasangan kelompok perlakuan dalam menurunkan kadar glukosa darah, maka analisa dilanjutkan dengan uji Mann-Whitney dengan taraf kepercayaan 95\%. Hasil uji MannWhitney menunjukkan perbedaan bermakna pada masing-masing kelompok, dengan tingkat signifikansi 0,002<0,005. Hal ini menunjukkan bahwa masingmasing kelompok memiliki efek penurunan glukosa darah yang berbeda.

\section{Hasil Perhitungan Persentase}

Hasil perhitungan persentase penurunan kadar glukosa darah semua kelompok perlakuan, diketahui bahwa semua kelompok perlakuan ekstrak etanol daun kacapiring mempunyai efek menurunkan kadar glukosa darah tikus putih jantan galur Wistar. Kelompok IV dengan perlakuan ekstrak etanol daun kacapiring dosis $250 \mathrm{mg} / \mathrm{kgBB}$ mempunyai efek menurunkan kadar glukosa darah sebesar 80,60\%. Kelompok III dengan perlakuan ekstrak etanol daun 
kacapiring dosis $500 \mathrm{mg} / \mathrm{kgBB}$ mempunyai efek menurunkan kadar glukosa darah 58,97\%. Sedangkan kelompok II sebagai kontrol positif dengan perlakuan glibenklamid dosis $1,35 \mathrm{mg} / \mathrm{kgBB}$ efek menurunkan kadar glukosa darah sebesar $73,93 \%$. Hasil perhitungan persentase penurunan kadar glukosa darah semua kelompok perlakuan dapat dilihat pada tabel III.

Tabel III. Hasil perhitungan persentase penurunan kadar glukosa darah semua kelompok perlakuan

\begin{tabular}{|c|c|c|}
\hline K & $\begin{array}{c}\text { LDDK0-300 } \pm \text { SD } \\
\text { (menit mg/dl) }\end{array}$ & $\begin{array}{c}\text { Persentase } \\
\text { penurunan } \\
\text { kadar } \\
\text { glukosa } \\
\text { darah } \\
\mathbf{( \% )}\end{array}$ \\
\hline I & $18503,98 \pm 182,43$ & 0 \\
\hline II & $4824,65 \pm 323,11$ & 73,93 \\
\hline III & $7592,55 \pm 1115,95$ & 58,97 \\
\hline IV & $3589,37 \pm 138,20$ & 80,60 \\
\hline
\end{tabular}

Keterangan :

$\mathrm{K}$ : Kelompok

KelompokI : Kontrol negatif dengan perlakuan CMC-Na 1\%

Kelompok II : Kontrol positif dengan perlakuan glibenklamid $1,35 \mathrm{mg} / \mathrm{kgBB}$

Kelompok III : Perlakuan dengan ekstrak etanol daun kacapiring dosis $500 \mathrm{mg} / \mathrm{kgBB}$

Kelompok IV : Perlakuan dengan ekstrak etanol daun kacapiring dosis $250 \mathrm{mg} / \mathrm{kgBB}$

Kemampuan menurunkan kadar glukosa darah kelompok IV lebih besar dibanding dengan kelompok kontrol positif, namun pada kelompok III kemampuan menurunkan kadar glukosa darah lebih kecil dibanding dengan kontrol positif. Dari hasil penelitian ini dapat dilihat dengan penurunan dosis 2 kali terjadi efek menurunkan kadar glukosa darah lebih besar, hal ini menunjukkan kemungkinan ada efek lain pada ekstrak etanol daun kacapiring yang lebih dominan dengan dosis yang lebih besar yang justru tidak mendukung efek antihiperglikemiknya.

\section{KESIMPULAN}

Ekstrak etanol daun kacapiring dosis $500 \mathrm{mg} / \mathrm{kgBB}$ dan $250 \mathrm{mg} / \mathrm{kgBB}$ dapat berefek menurunkan kadar glukosa darah. Ekstrak etanol daun kacapiring dosis $500 \mathrm{mg} / \mathrm{kgBB}$ dapat menurunkan kadar glukosa darah sebesar 58,97\% lebih kecil dibanding glibenklamid dosis $1,35 \mathrm{mg} / \mathrm{kgBB}$ yang dapat menurunkan kadar glukosa darah sebesar 73,93\%, sedangkan ekstrak etanol daun kacapiring dosis $250 \mathrm{mg} / \mathrm{kgBB}$ dapat menurunkan kadar glukosa darah sebesar $80,60 \%$ lebih besar dibanding glibenklamid dosis $1,35 \mathrm{mg} / \mathrm{kgBB}$.

\section{DAFTAR PUSTAKA}

Anonim, 1995, Farmakope Indonesia, Edisi IV, Hal : 410, DEpartemen Kesehatan Republik Indonesia.

Backer, C. A dan Van den Brink, R. C. B, 1965, Flora of Java, vol II N. V. P, Noordhoff, Croningen, The Netherlands

Dias T S, 1999, Leaflet Glucose GOD $P A P$, Diacnostic System (Diasys) Internasional.

Ganiswarna, S. G, 1995, Farmakologi dan Terapi, Edisi IV, Hal : 
467-481, Bagian Farmakologi, Fakultas Kedokteran Universitas Indonesia, Jakarta.

Katzung, B. G, 2002, Farmakologi Dasar dan Klinik diterjemahkan oleh Dripa Sjabana, Edisi VIII Buku 2, Hal : 672-709, Bagian Farmakologi Fakultas Kedokteran Universitas Airlangga, Surabaya.
Wijayakusuma, H, 2000, Tumbuhan Berkhasiat Obat Indonesia, Jilid I, Hal : 71-75, Prestasi Gema Insani, Jakarta.

Wiyono, P, 2004, Prevalensi Diabetes, Kabare Kagama No : 153/XXX/Mei/2004 